\title{
Chiral Discrimination of $\alpha$-Chiral Ammonium Ions by Sterically Geared Chiral Tripodal Oxazolines ${ }^{\dagger}$
}

\author{
Sung-Gon Kim, ${ }^{\ddagger}$ Sunderraman Sambasivan, and Kyo Han Ahn* \\ Department of Chemistry and Center for Electro-Photo Behaviors in Advanced Molecular Systems, POSTECH, \\ Pohang 790-784, Korea. *E-mail: ahn@postech.ac.kr \\ ${ }^{\ddagger}$ Department of Chemistry, College of Natural Science, Kyonggi University, Suwon 443-760, Korea \\ Received November 24, 2009, Accepted January 7, 2010
}

Key Words: Chiral discrimination, Organoammonium ions, Preorganization, Tripodal oxazolines

The concept of preorganization (conformational homogeneity) has been recognized as a fundamental design principle in the development of artificial receptors which have the ability to bind, signal or transport various types of cations, anions or neutral molecules. ${ }^{1}$ Various strategies have been employed to improve the preorganization characteristics of receptors, including structural designs like steric gearing, ${ }^{2}$ macrocyclization, ${ }^{3}$ fusing of multiple rings, ${ }^{4}$ immobilization on surfaces, ${ }^{5}$ etc.

We reported a new type of tripodal oxazoline receptors $1{ }^{6}$ which provides a $\mathrm{C}_{3}$ symmetric chiral environment toward $\alpha$-, $\beta$-, and $\alpha, \beta$-chiral primary organoammonium ions and related guests. ${ }^{6 a, 6 b}$ Receptor $1 \mathrm{a}$ in which $\mathrm{R}=\mathrm{Ph}$ provides a screw-sense chiral environment toward the $\alpha$-substituents of $\alpha$-chiral organoammonium ions (see Figure 1). Previously, chiral discrimination in this unique chiral environment was believed to be nonrealistic. ${ }^{7}$ We have demonstrated that a good level of chiral discrimination of $\alpha$-chiral organoammonium ions $(\sim 70: 30)$ can be realized in the $\mathrm{C}_{3}$ symmetric environment. If we compare the two diastereomeric complexes in a view of "three-body interactions", a substantial distinction in the steric interactions is noticeable, ${ }^{6 a}$ which indeed leads to a difference in the association constants. X-ray crystal structure analyses for the two diastereomeric complexes supported this explanation.

Tris(oxazoline) receptors 1 utilize a rigid 1,3,5-substituted benzene as a scaffold. Aiming at a possible improvement of the chiral discrimination ability of this class of receptors, we have evaluated the chiral discrimination with a 1,3,5-triethyl substituted oxazoline derivative $\mathbf{2 a}$. In this receptor, an increase in the 1,3,5-versus 2,4,6-facial segregation of the substituents around the benzene scaffold is expected, which may lead to an improvement in the chiral discrimination. In addition, we have also evaluated receptors $\mathbf{1 b}$ and $\mathbf{2 b}$, which have sterically demanding oxazoline ligands.

Receptors 2 are expected to adopt a conformation that favors an alternating "ababab" conformation ("1,3,5-up/2,4,6-down" conformation) to avoid otherwise increased steric repulsion between the vicinal substituents of the benzene frame. Use of such sterically bulky subunits within a molecule to enable it to adopt a thermodynamically favored conformation with minimum steric interactions has been dubbed as "steric gearing.",

All the receptors were synthesized from the 1,3,5-substituted

${ }^{\dagger}$ This paper is dedicated to Professor Sunggak Kim on the occasion of his honorable retirement. 2,4,6-tris(carboxymethyl)benzenes by previously reported methods. ${ }^{6 \mathrm{~d}}$ This time, we were successful in growing suitable single crystals of receptor $\mathbf{2 a}$ in contrast to the case of receptor 1a, for which we failed to get single crystals under various conditions. The X-ray crystal structure ${ }^{8}$ shows that 2a adopts an $a b a b a b$-conformation (Figure 3). An example is known in which the ligands have the "1,2,3-up/4,5,6-down" form, while its inclusion or coordination complexes adopt the "1,3,5-up/ 2,4,6-down" conformation in their solid structure. ${ }^{9}$ In the solid structure, the nitrogens of the oxazoline ligands do not point inward as in their ammonium complexes; instead, the oxazoline rings and their phenyl substituents form a bowl-shaped, $\mathrm{C}_{3}$ -

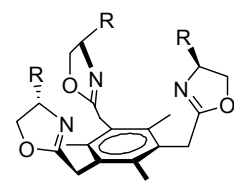

1

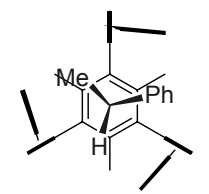

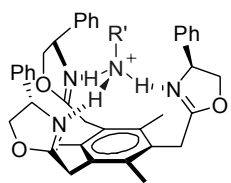

1a bound with $\mathrm{R}^{\prime} \mathrm{NH}_{3}{ }^{+}$

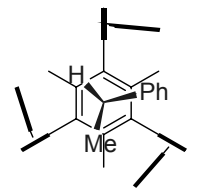

Figure 1. Benzene-based tripodal oxazoline receptors $(S, S, S)-\mathbf{1}$, an organoammonium complex of receptor $(S, S, S)$-1a, and schematic diagrams of top views for the two diastereomeric complexes between $(S, S, S)$-1 a and $(R)$ - and $(S)$-phenethylammonium ions $\left(\mathrm{NH}_{3}{ }^{+}\right.$moiety is omitted).

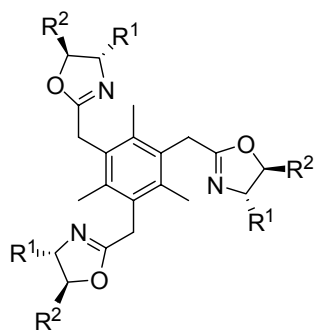

$$
\begin{aligned}
& \text { 1a, } R^{1}=P h ; R^{2}=H \\
& \text { 1b, } R^{1}=R^{2}=P h
\end{aligned}
$$

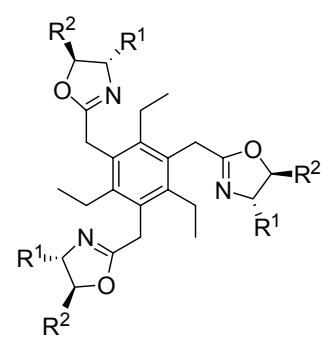

2a, $R^{1}=P h ; R^{2}=H$ 2b, $\mathrm{R}^{1}=\mathrm{R}^{2}=\mathrm{Ph}$
Figure 2. Tripodal oxazoline receptors evaluated. 


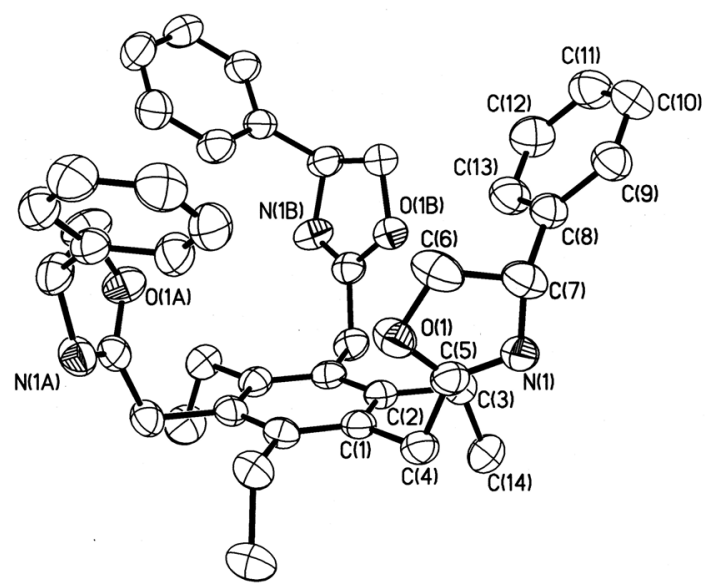

Figure 3. Crystal structure of receptor 2a.

Table 1. Selective binding of receptors $\mathbf{1 a},{ }^{a} \mathbf{1 b}, \mathbf{2 a}$, and $\mathbf{2 b}$ towards racemic $\alpha$-chiral organoammonium salts.<smiles>CC([NH3+])c1ccccc1</smiles>

Am1<smiles>CC([NH3+])c1ccc2ccccc2c1</smiles>

Am2

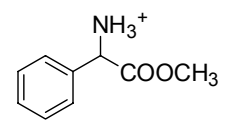

Am3

\begin{tabular}{cccc}
\multicolumn{2}{c}{ Am1 Am2 } & \multicolumn{2}{c}{ Am3 } \\
\hline receptor & $\begin{array}{c}\text { racemic } \\
\text { ammonium guest }\end{array}$ & enantioselectivity ${ }^{b}$ & $\begin{array}{c}\text { extraction } \\
(\%)^{c}\end{array}$ \\
\hline 1a & Am1 & $71(\mathrm{R}): 29(\mathrm{~S})$ & 82 \\
1a & Am2 & $71: 29$ & 99 \\
1a & Am3 & $78(\mathrm{~S}): 22(\mathrm{R})$ & 60 \\
\hline 2a & Am1 & $76(\mathrm{R}): 24(\mathrm{~S})$ & 38 \\
2a & Am2 & $73: 27$ & 57 \\
2a & Am3 & $87(\mathrm{~S}): 13(\mathrm{R})$ & 25 \\
\hline 1b & Am1 & $78(\mathrm{R}): 22(\mathrm{~S})$ & 60 \\
1b & Am2 & $77: 23$ & 82 \\
1b & Am3 & $76(\mathrm{~S}): 24(\mathrm{R})$ & 64 \\
2b & Am1 & $78(\mathrm{R}): 22(\mathrm{~S})$ & 58 \\
2b & Am2 & $74: 26$ & 43 \\
2b & Am3 & $90(\mathrm{~S}): 10(\mathrm{R})$ & 43
\end{tabular}

${ }^{a}$ Data taken from reference $6 \mathrm{a} .{ }^{b}$ Enantioselectivity of the ammonium ion extracted from excess racemic salts $\left(0.5 \mathrm{M} \mathrm{RNH}_{3}{ }^{+} \mathrm{Cl}^{-}\right.$in the presence of $0.6 \mathrm{M} \mathrm{NaPF}_{6}$ in $\left.\mathrm{D}_{2} \mathrm{O}\right)$ by the receptor $\left(0.05 \mathrm{M}^{\text {in }} \mathrm{CDCl}_{3}\right)$ at $25^{\circ} \mathrm{C}$. ${ }^{c} \mathrm{Per}-$ centage of the ammonium salts extracted into $\mathrm{CDCl}_{3}$ with respect to the receptor.

symmetric pocket. However, only a small conformational change from the solid structure seems to be needed to bind organoammonium ions.

The chiral discrimination of $\alpha$-chiral primary organoammonium ions by receptors $\mathbf{1 b}, \mathbf{2} \mathbf{a}$ and $\mathbf{2} \mathbf{b}$ was determined by the extraction experiment described in the previous report. ${ }^{6 a}$ Also, the enantioselectivity was determined by ${ }^{1} \mathrm{H}$ NMR analysis for the extracted mixture either directly (Am1 and Am2) or after derivatization into the corresponding Mosher's amide (Am3) as described previously. ${ }^{6 a, 6 b}$

Table 1 shows a comparison of the chiral discrimination of $\alpha$-chiral primary organoammonium ions by the highly sterically geared receptors $\mathbf{2 a}$ and $\mathbf{2 b}$ and also by sterically demanding oxazoline receptor $\mathbf{1 b}$ with that of the plain receptor $\mathbf{1 a}$.

The enantioselectivity data obtained with the sterically geared receptor 2a are higher than those obtained with their plain counterpart 1a. The enantioselectivity difference is also dependent on the ammonium substrates, showing a marked difference in the case of $\mathbf{A m 3}$ (78:22 vs. 87:13). Similarly, the more sterically geared 1,3,5-triethylbenzene based receptor $\mathbf{2 b}$ gives higher enantioselectivity than its 1,3,5-trimethyl counterpart $\mathbf{1 b}$. The higher enantioselectivities observed with receptors $\mathbf{2 a}$ and $\mathbf{2 b}$ compared to those obtained with $\mathbf{1 a}$ and $\mathbf{1 b}$, respectively, clearly demonstrate that an enhanced pre-organization of receptors by the steric gearing approach positively contributes to the chiral discrimination.

Introduction of sterically bulky substituents on the oxazoline ligands, such as 4,5-diphenyl analogue $\mathbf{1 b}$, also leads to an improvement in the chiral discrimination in the cases of Am1 and Am2, but a slightly deteriorating result in the case of Am3. When both the steric gearing and sterically demanding oxazoline ligands are thus combined together, as in the case of receptor $\mathbf{2 b}$, a very high enantioselectivity $(90: 10)$ is realized in the case of Am3. Such a high level of enantioselectivity is an impressive result considering that the receptors are highly flexible. A high level of chiral discrimination of $\mathbf{A m} \mathbf{3}$ has rarely been achieved previously. ${ }^{10}$

The increase in chiral discrimination on steric gearing can be rationalized in the following manner. Sterically geared receptors $\mathbf{2} \mathbf{a}$ and $\mathbf{2 b}$ are highly preorganized with optimum positioning of the three oxazoline rings on the same side of the benzene scaffold. This preorganization enables the phenyl substituents of the oxazoline rings to form a "hydrophobic wall" that encompasses the guest in a propeller-shaped, $\mathrm{C}_{3}$-symmetric chiral environment, an important molecular interaction in forming host-guest complexes along with the tripodal hydrogen bonding.

It is also seen that the 1,3,5-triethylbenzene-based receptors $\mathbf{2 a}$ and $\mathbf{2 b}$ show decreased percent extraction values than those obtained with 1,3,5-trimethylbenzene-based receptor $\mathbf{1 a}$ or $\mathbf{1 b}$ (Table 1). The extraction involves the partition process of hostguest complexes between organic and aqueous media and thus seems not to be directly correlated with the enantioselectivity.

In summary, we have demonstrated that enhancing the preorganization of tris(oxazoline) receptors into a preferred conformation by a steric gearing strategy leads to an improvement in their enantioselectivity toward several $\alpha$-chiral organoammonium ions. Thus tris(oxazoline) receptors based on 1,3,5-triethylbenzene skeleton, $\mathbf{2} \mathbf{a}$ and $\mathbf{2} \mathbf{b}$, give higher enantioselectivities than 1,3,5-trimethylbenzene-based receptors $\mathbf{1 a}$ and 1b, respectively. Also, we have shown that increasing the steric bulkiness of the oxazoline ligands results in an improvement, although not dramatic, in the enantioselectivity in most cases. By combining both factors, a very high enantioselectivity of 90:10 is realized.

\section{Experiments}

Synthesis of the receptors. All the receptors were synthesized from the 1,3,5-substituted-2,4,6-tris(carboxymethyl)benzenes and the corresponding amino alcohols according to the 
previously reported methods. ${ }^{6 \mathrm{a}, 6 \mathrm{~d}}$ Only it is necessary to mention about the synthesis of 1,3,5-tris(bromomethyl)-2,4,6-triethylbenzene, in which the bromomethylation step requires harsh reaction conditions compared to that of 1,2,5-trimethylbenzene. ${ }^{6 a}$ For this reason, zinc bromide was added in addition to $30 \% \mathrm{HBr}$ in acetic acid. To a mixture of 1,3,5-triethylbenzene $(21.0 \mathrm{~g}, 0.13 \mathrm{~mol})$, paraformaldehyde $(38.7 \mathrm{~g}, 1.30 \mathrm{~mol})$ and zinc bromide (34.9 g, $0.16 \mathrm{~mol}$ ) was added $30 \mathrm{wt} \% \mathrm{HBr} /$ acetic acid solution $(323 \mathrm{~mL})$ rapidly. The mixture was stirred for $30 \mathrm{~h}$ at $90{ }^{\circ} \mathrm{C}$. Upon cooling to the room temperature, the tribromide began to crystallize readily, which was collected by filtration, and the filtrate was washed with water and dried for several hours in vacuo. The filtered solution was stirred for another $30 \mathrm{~h}$ at $95{ }^{\circ} \mathrm{C}$, which, upon cooling, afforded a further fraction. In the two cycles, $28.1 \mathrm{~g}$ and $7.1 \mathrm{~g}$ of the product were obtained respectively $(80 \%)$.

The next steps, the substitution by cyanide [13.3 $\mathrm{g}$ of the tribromide and $15.9 \mathrm{~g}$ of $\mathrm{NaCN}$ in $\mathrm{MeOH}(150 \mathrm{~mL})$-water (25 $\mathrm{mL}$ ), reflux $6 \mathrm{~h} ; 76 \%$ yield after recrystallization from dichloromethane-hexane] and the hydrolysis of the cyanide [28.0 g of the cyanide in a 1:1:1 (by volume) mixture of $\mathrm{H}_{2} \mathrm{SO}_{4}-\mathrm{AcOH}$ water (total $450 \mathrm{~mL}$ ) and reflux for $22 \mathrm{~h}$; $98 \%$ yield] were carried out without any difficulty. The final oxazoline formation from the triacid was carried out via the corresponding acid chloride in one-pot reaction according to the established procedures.

Chiral discrimination. The chiral discrimination of $\alpha$-chiral primary organoammonium ions by receptors $\mathbf{1 b}, \mathbf{2} \mathbf{a}$ and $\mathbf{2 b}$ was determined by the extraction experiment as described in the previous report. ${ }^{6 a}$ Also, the enantioselectivity was determined by ${ }^{1} \mathrm{H}$ NMR analysis for the extracted mixture either directly (Am1 and Am2) or after derivatization into the corresponding Mosher's amide (Am3) as described previously. ${ }^{6 \mathrm{a}, 6 \mathrm{~b}}$

Acknowledgments. This work was supported by a grant from the EPB center (R11-2008-052-01001).

\section{References}

1. (a) Lehn, J. M. Supramolecular Chemistry, Concepts and Perspective; VCH: Weinheim, 1995. (b) Still, W. C. Acc. Chem. Res. 1996, 29, 155. (c) Cram, D. J. Angew. Chem. Int. Ed. 1988, 27, 1009.

2. (a) Hennrich, G.; Anslyn, E. V. Chem. Eur. J. 2002, 8, 2218. (b) Hoffmann, R. W. Angew. Chem. Int. Ed. 2000, 39, 2055.

3. (a) Alexander, V. Chem. Rev. 1995, 95, 273. (b) Izatt, R. M.; Pawlak, K.; Bradshaw, J. S.; Bruening, R. L. Chem. Rev. 1995, 95, 2529.

4. Perreault, D. M.; Chen, X.; Anslyn, E. V. Tetrahedron 1995, 51, 353.

5. Descalzo, A. B.; Martinez-Manez, R.; Sancenon, F.; Hoffmann, K.; Rurack, K. Angew. Chem. Int. Ed. 2006, 45, 5924.

6. (a) Kim, S.-G.; Kim, K.-H.; Jung, J.; Shin, S. K.; Ahn, K. H. J. Am. Chem. Soc. 2002, 124, 591. (b) Kim, S.-G.; Kim, K.-H.; Jung, J.; Kim, Y. K.; Shin, S. K.; Ahn, K. H. J. Am. Chem. Soc. 2003, 125, 13819. (c) Ahn, K. H.; Kim, S.-G.; Jung, J.; Kim, K.-H.; Kim, J.; Chin, J.; Kim, K. Chem. Lett. 2000, 170. (d) Kim, S.-G.; Ahn, K. H. Chem. Eur. J. 2000, 6, 3399. (e) Kim, K.; Raman, B.; Ahn, K. H. J. Org. Chem. 2006, 71, 38.

7. (a) Zhang, X. X.; Bradshaw, J. S.; Izatt, R. M. Chem. Rev. 1997, 97, 3313. (b) Löhr, H.-G.; Vögtle, F. Acc. Chem. Res. 1985, 18, 65.

8. Crystal data for 2a: $0.40 \times 0.40 \times 0.60 \mathrm{~mm} \mathrm{C}_{42} \mathrm{H}_{45} \mathrm{~N}_{3} \mathrm{O}_{3}, M_{r}=$ 639.81, cubic, space group I23, $a=19.7093(3), b=19.7093(3)$, $c=19.7093(3) \AA, \alpha=90^{\circ}, \beta=90^{\circ}, \gamma=90^{\circ}, V=7656.2(2) \AA^{3}, Z=$ $8, T=223(2) \mathrm{K}, \rho_{\text {calcd }}=1.110 \mathrm{Mg} / \mathrm{m}^{3}$, Wavelength $=0.71073 \AA$, 15705 reflections collected, 2039 independent reflections, $R 1=$ $0.0679, w R 2=0.1775[\mathrm{I}>2$ (I)], $R 1=0.0740, w R 2=0.1882$ (all data), GOF $=1.174$. Crystallographic data for 2a has been deposited with the Cambridge Crystallographic Data Centre as supplementary publication no. CCDC-755653. These data can be obtained free of charge via www.ccdc.cam.ac.uk/data request/cif, or by emailing to data_request@ccdc.cam.ac.uk, or by contacting the Cambridge Crystallographic Data Centre, 12, Union Road, Cambridge CB2 1EZ, UK; fax: +44 1223336033.

9. Chin, J.; Walsdorff, C.; Stranix, B.; Oh, J.; Chung, H. J.; Park, S.-M.; Kim, K. Angew. Chem. Int. Ed. 1999, 38, 2756.

10. (a) Newcomb, M.; Toner, J. L.; Helgeson, R. C.; Cram, D. J. J. Am. Chem. Soc. 1979, 101, 4941. (b) Armstrong, A.; Still, W. C. J. Org. Chem. 1992, 57, 4580. 